\title{
CHIEFTAINCY, LABOUR CONTROL AND CAPITALIST DEVELOPMENT IN CAMEROON
}

Piet Konings

Two major prerequisites for capitalist development are (i) the procurement of a regular and adequate supply of labour and (ii) the establishment of managerial control over the labour process in order to raise labour productivity. Their realization may be particularly problematic in areas where the capitalist mode of production has not yet deeply penetrated and where the majority of the population has neither been completely severed from the means of production nor internalized the norms and values of capitalism. Rural producers, still strongly rooted in non-capitalist forms of organization and value systems, may resist entry into the capitalist labour market and habituation to the capitalist work rhythm and ethic. Chieftaincy in Africa has played a significant mediating role between capital and labour in the realization of capitalist objectives.

Regarding the establishment of capitalist control over labour supplies, there is now abundant literature on the intermediary role of chiefs in the supply of local male labour to capitalist enterprises, particularly in the early colonial period. Despite some initial resistance, chiefs were soon forced to assist in meeting the growing capitalist demand for male labour, and many of them eventually 'capitalized' on their intermediary role in various ways. Unfortunately, far less attention has been paid to the concomitant widespread opposition of chiefs to female migration and proletarianization. They opposed it on the grounds of women's vital productive and reproductive labour and their subordination to 'patriarchal' controls in many African societies (Stichter and Parpart 1988). In 1952, just a few years before the introduction of estate tea production in the Bamenda Grassfields of Cameroon, Phyllis Kaberry published her classic study Women of the Grassfields. Throughout her book she emphasizes the ambiguous position of women in society. On the one hand, there is a general recognition of women's indispensable role in society as child bearers and food producers. On the other hand, they are subordınated to patriarchal

○ Copyright 1996 - Piet Konings 
controls. These contradictions in women's position may not be as puzzling as they first seem, however. Control over women's vital productive and reproductive labour constituted the basis of men's prestige, power and wealth in society. In a recent study of women in the Grassfields, Goheen perceptively observes:

\begin{abstract}
Women grew the food crops and were expected to provide the necessities of daily life from their farms. Women's productive labour forced men to participate in (lucrative) trading networks; their reproductive labour increased the size of the household and thus the status and the labour force of the male head. Any surplus value women produced over and above that required for household needs and petty barter was in the hands of men, who retained all the profits. (Goheen 1993: 243)
\end{abstract}

Chiefs in Africa have frequently tried to safeguard male control over women's productive and reproductive labour in their local communities, arguing that it was an essential part of African 'traditions'. Women who succeeded in escaping from patriarchal controls and migrated to towns had to endure social ostracism as 'prostitutes' for the rest of their days (Obbo 1980). Chiefs repeatedly appealed to colonial authorities to use state power to help keep women under control. Relying on the chiefs for the maintenance of order in the rural areas, the authorities were inclined to side with them, taking legislative and administrative measures to strengthen patriarchal dominance (Chauncey 1981). From time to time, single women living in colonial towns were rounded up by the police and forcibly returned to their villages (Obbo 1980; Ruel 1960; Walker 1982).

Articulation theorists like Meillassoux (1975) and Wolpe (1980) have argued that the supplying of exclusively male labour to capitalist enterprises was functional to capital accumulation, as women's continual productive and reproductive responsibilities in the non-capitalist sector served to lower labour costs in the capitalist sector. While these theorists often assume a joint interest of chiefs and employers in keeping women confined to the non-capitalist sector, the actual situation may have been more complex, and it was certainly more dynamic. Chauncey (1981) and Parpart (1986) note that the copper mines in Zambia initially favoured the employment of single men. By 1944, however, mine owners had agreed that married men's greater stability and productivity more than compensated them for the extra costs of housing and feeding the latter's wives and children. They therefore became increasingly committed to married labour. Thus, contrary to the articulation model, the ability of capital in Zambia to extract greater surplus value depended on its success in relocating women's reproductive labour to the urban areas. The colonial state, however, responding to the chiefs' complaint that female migration to the Copperbelt towns was threatening both their authority over women and food production, implemented a series of measures to block migration of women to the towns. This 


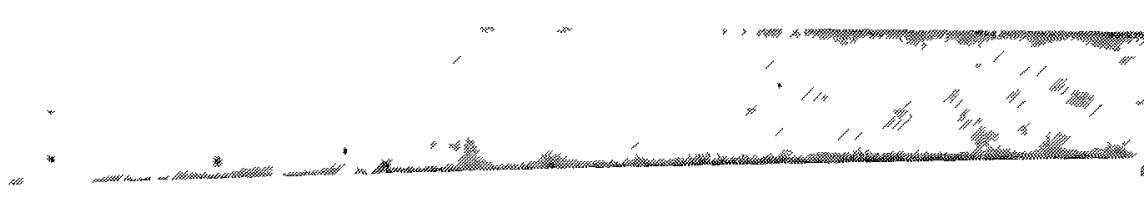

JOURNAL OF LEGAL PLURALISM

1996 - nr. 37-38

resulted in one of the most serious confrontations between the state and capital during the colonial period.

In this study I will argue that tea estates were among the rare capitalist enterprises during colonial rule that gave preference to female labour over male labour. The managerial attempt to recruit female pluckers on a newly created tea estate in the Bamenda Grassfields of Cameroon immediately gave rise to a serious confrontation with the local chief, who feared female employment on the estate would endanger 'traditional' patriarchal control over female labour, and who therefore insisted on exclusive recruitment of local male labour.

Concerning the establishment of capitalist control over the labour process, it would appear that the attempts of management and state to co-opt chiefs and 'tribal elders' or 'representatives' or 'heads' into the hierarchy of authority over the labour process have been insufficiently studied.

In the British African colonies the first such attempt was apparently made in the early thirties. It must be situated in a context of growing concern in the British Colonial Office with massive labour migration, poor working and living conditions of labourers, and the first strike waves in Africa. Various suggestions were made to solve the 'labour problem'. One was the institutionalization of channels of communication between workers, management and colonial administration. On 17 September 1930, Sydney Webb (Lord Passfield) circulated a dispatch to all colonial governors urging the legalization of 'sympathetically supervised and guided' trade unions and the creation of Labour Departments in the different colonies (Meebelo 1986: 191-92; Freund 1981: 174). Most colonial officials and employers, however, were openly antagonistic to the development of trade unions and postponed their introduction. They argued that the necessary conditions for the emergence of trade unions were lacking: most workers were illiterate and still firmly encapsulated in 'tribal' organization and culture. It was therefore believed that 'traditional', ethnically-based channels of communication would be more suitable in the African environment than 'modern', class-based channels of communication such as trade unions.

In his pioneering study, Epstein (1958) describes the creation of a system of 'Tribal Elders' by the mine management in Zambia. The miners were asked to elect representatives of their own ethnic groups on a Council of Tribal Elders. This council was supposed to represent the interests of the workers to the company and communicate company policy to the workers. Epstein shows that this managerial strategy of co-opting tribal elders as brokers in the mine hierarchy was quickly challenged by the workers. First, the miners tended to identify themselves as workers rather than as 'tribesmen', at least in the field of industrial relations, and to develop class-based interests. And secondly, the newly elected brokers soon came to be 


\section{CHIEFTAINCY AND LABOUR CONTROL \\ Piet Konings}

denounced as management stooges, losing any support they had ever enjoyed. Equally important to the rejection of tribal representatives was the miners' adoption of organizational forms which gave expression to their class interests. Thus, during the 1940 disturbances, workers at Mufulira picked leaders from among their own ranks to express their grievances. Following the Second World War, the Labour Department assisted workers in organizing a trade union. As Epstein notes, the formation of the union signalled the eclipse of the system of tribal elders/representatives. Many conflicts occurred between the young, educated union leaders and the older, illiterate tribal representatives, with both sides trying to capture the miners' loyalty. In 1953 the union organized a referendum on the future of ethnic representation. Under strong urging by union leaders, the miners voted overwhelmingly to abolish the system.

Crisp (1984: 70) has recorded that, despite the promulgation of a Trade Union Ordinance in 1941, the first Commissioner of Labour in Ghana, Captain J.R. Dickinson, remained strongly opposed to the encouragement of unionization. Stressing the importance of good relations between the administration and the traditional elite, he recommended that, since the chiefs were accustomed to representing their people, they should likewise act as representatives of workers living within their areas of jurisdiction. He even felt this system would have "all the effect of the Trade Unions and comes to the same thing in the end". This view was not shared by the Colonial Office, the Governor, or indeed the workers, who insisted that trade union officials should act as brokers between labour, management and government. Dickinson's proposal was promptly abandoned. Crisp (1984: 76) and Robotham (1989: 42) mention that the gold mines in Ghana promoted a system of compound chiefs for each resident ethnic group in the mines. Crisp $(1984: 119,182)$ claims this system was created by the management in order to divert attention from the real power conflicts within the mines, which ran along class lines. He is of the opinion, however, that despite several attempts by management to bolster the authority of the tribal heads after 1937, the latter nevertheless remained a feeble component in the authority structure in the mining industry.

Crisp's opinion has been criticized by Lentz and Erlmann (1989). They provide evidence that at least some of these tribal heads in the Ghanaian gold mines have played key roles as brokers between workers, management and (local) government. Moreover, unlike Epstein and Crisp, who tend to view tribal elders or heads in the Zambian and Ghanaian mines predominantly as manifestations of control strategies by corporate capital and colonial administration, they stress the ambiguous role of these brokers in the relationship between workers and management. On the one hand, tribal heads tended to be part of the mine management, and as such they functioned as controllers of labour. On the other hand, they often defended the interests of members of their ethnic group and provided them with a range of services: accommodation and job opportunities for new migrants; settlement of internal 
disputes; support in emergencies such as sickness, accidents and deaths; and mediation in conflicts with management, local authorities, and other ethnic groups. Lentz and Erlmann even point out that an important Dagara chief in the Tarkwa Goldmines was involved for some time in both management and union, sitting on the union's executive in his capacity of chief adviser for the Dagara community. Contrary to Epstein and Crisp, they suggest that workers continue to have multiple identities and loyalties in the workplace: they are both workers and 'tribesmen'. In principle, therefore, chieftaincy could still play a mediating role alongside the union. Nevertheless, Lentz and Erlmann found that the mediating role of chieftaincy in the mines had eroded for various reasons. Tribal heads no longer occupy an important position in the mine hierarchy. Internal divisions in ethnic groups have also weakened chiefly authority and responsibility with regard to internal community affairs. Simultaneously, one may observe the emergence of 'big men' in the mines who serve as ethnic brokers, and the formation of ethnically based voluntary associations. Such associations not only assume the obligations of tribal chiefs with regard to mutual assistance; they also help effect a transition to modern, more participatory forms of political decision-making.

The tribal elders, representatives or heads in the Zambian and Ghanaian mines were more or less managerial creations. Their authority had no basis in 'tradition' and their mediating role between labour and capital rested ultimately on managerial recognition. Interestingly, both Epstein and Lentz and Erlmann note that most of them tried to establish, or claimed already to have, close relationships with royal families in the rural areas. In fact, they owed their prestige among the people to the fact that they were often close kinsmen of chiefs. Indeed, they usually described themselves as chiefs. To legitimize their authority among the people, they tried to 'traditionalize' their appointment by adopting chiefly ceremonies, rituals and attributes. All this seems to indicate the persistence of 'traditional' political values among ethnic communities in industrial milieus.

Most authors also refer to the strategy of management and state to involve 'real' chiefs in labour control, especially in critical situations such as strike actions. These were usually paramount or other prominent chiefs who continued to wield considerable power over the workers. They sided mostly with management and the state, and helped put down strikes. Crisp (1984: 102), for example, reports that in 1949 the Chamber of Mines in Ghana invited a group of prominent northern chiefs to the mines, who told the northern workers to ignore any strike call of southern union officials, who were said to be pursuing purely political objectives. Sometimes, however, these chiefs also appear to have identified with the workers and defended their interests. According to Crisp (1984: 109), northern chiefs, who were recruited in the early fifties to assist the recruitment drive for the mines, were becoming increasingly critical of conditions in the mines. Mine managers found to their horror that in their visits to the south the chiefs were actually "allying themselves with the 


\section{CHIEFTAINCY AND LABOUR CONTROL Piet Konings}

union" and making demands for higher wages.

What all these authors have in common is that they assume that the mediating role of chieftaincy between labour and capital has either come to an end or been seriously eroded in Africa. This is particularly due to the emergence of new values, institutions, and holders of power in society and capitalist enterprises which are to have made this role obsolete. The present study explores to what extent this assumption holds true, taking into account the emphasis placed in recent anthropological studies on the resilience and dynamics of neo-traditional values, institutions and authority patterns in 'modernizing' societies (Geschiere 1989; van Binsbergen 1993). To this end, I carried out intensive fieldwork in 1991 on the role of chieftaincy in labour recruitment and labour control in estate tea production at $\mathrm{Ndu}$, a small Wimbum town in the northeastern part of the Bamenda Grassfields in Cameroon. Wimbum society, like most other societies in the Bamenda Grassfields, is characterized by a highly complex sociopolitical form of organization headed by powerful, even sacred, chiefs (or Fons as they are called throughout the Grassfields) (Jeffries 1962; Chilver and Kaberry 1967; Nkwi and Warnier 1982). Fisiy stresses the 'traditional' and 'religious' foundation of their authority:

The founding of most of the chiefdoms in [the Bamenda Grassfields] is based on a myth of origin that tended to confer temporal power on those repositories of traditional authority. For the Fon, the source of legitimacy is shrouded in myth and ritual orderings which give a spiritual content to the exercise of his authority. This is because the lineage through which the myth was initially transmitted had contact with the deities and the ancestors... This has safeguarded the sanctity and spirituality of the institution of the Fon....

This conceptualization of the institution of the Fon, based on sacred attributes, has tended to sustain powerful chiefs who still maintain a firm spiritual and moral grip over their people. (Fisiy 1992: 212)

The chief of Ndu is the most influential of the Wimbum chiefs and is for this reason seen by some as the leader of all the Wimbum. Although steeped in tradition and religious belief, chiefly power is nevertheless subject to various checks and balances. The chief is responsible for, and accountable to, his people. He used to be assisted in the execution of his responsibilities by quarter-heads, councillors and a number of other important (hereditary) title- and office-holders. He still seeks regular advice from these 'traditional' holders of power in his area of jurisdiction.

It needs to be pointed out, however, that chiefly power has been challenged of late 


\section{JOURNAL OF LEGAL PLURALISM}

1996 - nr. 37-38

by two new developments (Fisiy 1992). First, there is the emergence of a modern elite in Ndu, who want to have a greater say in the affarrs of the local community. This group has established a 'Development Committee' responsible for the planning and implementation of development projects at Ndu (Probst and Bühler 1990). With their knowledge, wealth and influence, they act as advisers to the chief. As a result of this recent development, the members of the traditional elite, who tend to be illiterate, play an increasingly marginal role in the local decision-making process. One of the chief's strategies to accommodate the emergence of rival sources of power is to incorporate the modern elite into the 'traditional' authority structures. By conferring (non-hereditary) titles to the modern parvenus, he co-opts them into the existing hierarchy and expects them to hold their newly acquired offices for the benefit of the community. A second new development is that, in the wake of the promulgation of Decree no 77/245 of 15 July 1977, the 'traditional chiefs' have been turned into auxiliaries of the administration and reduced to the lower ranks of the local bureaucracy.

\section{Chieftaincy and Control of Labour Supplies at the Ndu Tea Estate}

During the early 1950 s the British administration began promoting estate tea production in its Trust Territory of the Southern Cameroons. The Cameroon Development Corporation (CDC), a huge agro-industrial parastatal (Konings 1993), opened a tea estate at Tole, near Buea, in the coastal plantation area. In 1955/56 a British-Indian multinational enterprise, the Estates and Agency Company Ltd (EAC), which by that time already owned eleven tea estates in India and Sri Lanka as well as mines and a hotel chain in various parts of the world, was invited by the British to examine the possibilities of creating a second tea estate in the Bamenda Grassfields, the 'traditional' labour reserve to the coastal plantations.

The EAC eventually concluded that the soils and climate at Ndu were suitable for estate tea production. Accompanied by two local parliamentarians, an EAC negotiation team approached the chief of Ndu, His Royal Highness William Nformi, and requested him to allocate land for the creation of a tea estate. The two deputies tried to convince the chief of the benefits of estate tea production: it would stimulate local development and halt the growing flow of labour to the coastal plantations. The chief told the negotiation team that although he highly favoured any project that would stimulate local development, he nevertheless feared that employment on the estate might have a negative effect on his subjects' loyalty to 'traditional' value systems and authority patterns. He therefore made the allocation of a vast area of approximately 1,660 ha for estate tea production conditional upon the company's acceptance of the following rules: no employment of female labour and the exclusive recruitment of local male labour. 


\section{CHIEFTAINCY AND LABOUR CONTROL Piet Konings}

The chief's rejection of female employment on the estate was a great disappointment to the EAC negotiation team, which had informed him that the company preferred female pluckers to male ones. There were several reasons for the company's preference for female labour, including the following.

First, there was a general belief in management circles that women were naturally more suited to pick tea (they had 'nimble fingers'), were more docile (they were habituated to subordination) and were cheaper (their income was defined as supplementary to that of the so-called breadwinner, the husband). The company's long experience with tea plucking in India and Sri Lanka had strengthened these managerial beliefs (Elson and Pearson 1984; Kurian 1982). The idea of enjoying similar benefits on a tea estate in Cameroon must have been particularly attractive to management.

Second, tea plucking had to a large extent become identified as 'women's work', due to the high employment rate of women on the tea estates in Asia and elsewhere.

Third, the EAC management was insensitive to the possible differences between the African and Asian sociocultural situation with regard to the position of women. Small wonder that the EAC negotiation team questioned the chief as to why women in Cameroon could not be engaged in tea plucking like their sisters in Assam.

Being strongly convinced that the employment of women on the estate would challenge the 'traditional' male control over women's productive and reproductive labour, the chief refused to discuss the matter. He bluntly told the negotiation team that female workers would be inclined to neglect food production on the family farms and to become 'harlots'. In the end, however, he agreed that some women might be employed on the estate for specific activities, particularly weeding, on a casual or temporary basis, provided their employment would not affect their productive and reproductive responsibilities in the local community. There is no doubt that Ndu men appreciated the chief's firm defence of 'traditional' norms, for there is ample evidence that they persistently impeded Wimbum women's employment on the estate. Most women who started work on the estate on temporary weeding contracts originated from the neighbouring Nso area. They faced a tough time on the estate. Several reports mention that the male workers engaged in various modes of resistance against the women's employment. On 8 November 1962, the first estate manager, Mr J.M.H. Barrable, lodged a complaint with the union about this behaviour of the men:

Recently, there were many women who reported that they had been threatened in various ways should they work on contracts on the estate...This is not in the interest of the estate. At certain times of the year, work becomes out of hand due to the quick growth of 
weeds, and only by employing contract workers can this be held in check. ${ }^{1}$

In 1982, the old chief died. His successor was a university graduate. His installation illustrates the growing tendency in the Bamenda Grassfields from the 1970s onwards to enthrone well-educated youths who, it was believed, could blend 'modern' with 'traditional' values. Rather than conservatively adhere to the local culture, these chiefs would be inclined to subject some long-standing customary tenets to strict scrutiny and eventually modify them to keep pace with changing times. The new chief at Ndu appeared well aware of the changing position of women in Cameroonian society. One year after his enthronement, in 1983, he allowed the CDC, which had taken over the estate from the EAC in 1977, to employ women as pluckers on a permanent basis. Interestingly, I found that male opposition to female employment on the estate did not disappear altogether after this agreement between the chief and the CDC management. This is clearly reflected in the records of shop stewards' meetings:

On 6 April 1983, one of the shop stewards wanted to know why male workers are being terminated but females do a continuous job.

On 10 June 1986, it was remarked that one should be very careful in employing women on the estate because some of them tended to abandon their husbands in order to work on the estate. ${ }^{2}$

Many male workers told me that they had become used to female employment on the estate, yet they would never allow their wives to work there.

The persistent male opposition is also evident in the size and characteristics of the female labour force on the estate. The number of women employed on the estate continues to be small: only $6.5 \%$ of the estate's total labour force are women, $73 \%$ of them having been recruited after 1983 . They tend to be much younger and better educated than the men. These are precisely the women who tend to resist the 'traditional' female roles and patriarchal controls in the local community. Although they would prefer a job less arduous than plantation work and more in line with their

1 Letter of Mr J.M.H. Barrable, Estate Manager, Ndu Tea Estate, to General Secretary of NEWU, dated 8 November 1962, in File CUPIAW 7, Joint Consultative Committee Members' Meetings and Outcome.

2 CDC Ndu Tea Estate, Records of Minutes of Staff Representatives' Preparatory Meetings, 1981-1991. 


\section{CHIEFTAINCY AND LABOUR CONTROL \\ Piet Konings}

educational achievements, they have no alternative but to work on the estate for the time being.

Besides rejecting female employment on the estate, the old chief had insisted during negotiations with the EAC team on the exclusive recruitment of local male labour, preferably from Ndu and nearby villages. He argued that this rule would not only halt male labour migration to the coastal plantations, but also eliminate the need for labour camps, common in the coastal plantations. This rule seemed mutually advantageous. For the company it was a cost-saver: there was no need to invest in workers' accommodation and other social welfare services. For the chief it was a controlling device: he wanted to ensure that the estate workers would continue to be integrated into the local community and adhere to 'traditional' norms and authority. For the workers, however, it was a source of contradictions. They in essence became subjected to a dual authority: managerial authority at work and chiefly authority in the local community. As a result, they were often faced with a difficult dilemma: whether to adhere to capitalist work norms or to 'traditional' norms, both options being surrounded with sanctions from the respective authorities. In conformity with this rule, the company initially implemented a strict policy of recruiting its labour force from Ndu itself and neighbouring villages within a radius of five kilometres from the estate. However, when employment opportunities on the estate increased after the tea bushes came to maturity, the management also began employing men from more distant Wimbum villages and from nearby ethnic groups. Both management and the chief, however, continued to oppose the union's demand for the building of labour camps.

\section{Chieftaincy and Labour Control at the Ndu Tea Estate}

The creation of the Ndu Tea Estate in January 1957 marked the start of a 'development coalition' (Bates 1981) between the chief and management. At that time, the newly created estate was the only agroindustrial enterprise in the entire Bamenda Grassfields and one of the rare enterprises in the region offering wage employment to a substantial number of people: the labour force grew from approximately 300 in $1957 / 58$ to more than 1,500 in the early 1980 s. The chief strongly believed that the company would stimulate local development and raise his subjects' living standards. He was therefore greatly concerned that the company should operate in peace and harmony so that nothing would disturb its continued existence and prosperity. He performed certain rites annually to protect the company against any misfortune. He regularly admonished the workers to be disciplined and productive, to keep to company rules and obey managerial staff, and to refrain from disrupting production in any way. Initially he vehemently opposed development of trade unionism, which he perceived as a threat to managerial and chiefly authority alike. He has continued to condemn any strike action and to assist in quelling strikes 
to intervene "as the workers are not at rest and look very belligerent at this attitude of management and the chief". ${ }^{3}$

The vehement opposition of chief and management could not impede the growing popularity of the union as it persevered in defending workers' interests. An increasing number of workers were accusing the chief of betraying his subjects' interests and of identifying totally with the objectives and actions of the management. The union's successful organization of a first strike in 1962 boosted worker confidence in the union leadership and eventually forced the chief and the management to recognize the union.

The strike started on 18 June 1962, following the estate manager's refusal to discuss a long list of grievances presented by the union. There were violent clashes between strikers and strike-breakers and between strikers and police. Twenty-three workers were arrested. The strikers then assembled at the Ndu market armed with sticks, cutlasses and spears and singing battle chants. They threatened to free their colleagues. Only the union's General Secretary managed to restore order.

The chief tried to intervene in the strike on 22 June. He called upon the General Secretary to start negotiations with the estate manager at his palace. The General Secretary turned down his request. He told the chief that if the estate manager wanted to start negotiations, he should approach the union directly.

The strike lasted until 20 July, when a settlement was reached in a meeting with the Senior Labour Officer of the government, who acted as a conciliator. This settlement resulted in various improvements in the working conditions on the estate. It was also followed by a rapid increase in union membership. Gradually, the chief and the management came to accept the union as the 'normal' mediation channel between the workers and the management. Since then the relationship between the union leadership and the chief has improved considerably. There are now regular consultative meetings between the union leadership and the chief. Some union leaders are members of the 'Development Committee', the informal organization of Ndu elite which advises the chief on development issues. Others are hereditary and nonhereditary title-holders in Wimbum secret societies. In 1987, a brother of the present chief, a clerical officer, was elected union president. His close connection with the chiefly family was a principal reason for his election.

3 See Letter of Mr E.Y.K. Barthson, General Secretary of NEWU, to Senior Labour Officer, Buea, dated 22 October 1962, in File CUPIAW 7, Joint Consultative Committee Members' Meetings and Outcome; and Letter of Mr E.Y.K. Barthson, General Secretary of NEWU, to Estate Manager, Ndu Tea Estate, dated 6 November 1962, ibid. 


\section{JOURNAL OF LEGAL PLURALISM \\ 1996 - nr. 37-38}

Following his recognition of the union, the chief's role in labour control on the estate has been restricted mainly to warning the workers from time to time to be disciplined and productive in the labour process, as well as to assisting in averting and putting down strikes. For example, on the occasion of the workers' welcoming ceremony to the CDC management on 9 April 1977, the chief told the workers:

I say honesty is the key to success. That all workers should be serious at their work and that I shall not support anybody caught as a thief. ${ }^{4}$

State authorities and management staff continue to call upon the chief during the frequent strike actions on the estate. They believe that the chief still has a spiritual and moral grip over his subjects, and is thus a valuable asset in labour control.

It must, however, be pointed out that the chief's role has not always been conducive to labour control. From time to time he has advised management staff to study the 'traditional' Wimbum norms and customs. ${ }^{5}$ He stresses that this would help them better understand the dilemmas of estate workers still strongly rooted in the 'traditional' organization and ethic: these workers must frequently decide whether to act upon 'traditional' norms or capitalist work norms. In this connection, the chief has tended to plead for a measure of managerial 'leniency' towards workers who absent themselves from work due to 'traditional' obligations. There is evidence that the management has sometimes complied with the chief's advice. For example, during the annual harvesting period of maize in August-September, the men are customarily obliged to assist the women in the transport of the harvest from the farm to the compound. When this period approaches, the rate of absenteeism on the estate tends to rise. On the chief's advice, the EAC management was inclined to be less rigorous in its control of absenteeism during this period. It generally sanctioned only those workers who seemed to take undue advantage of its 'leniency', i.e. were absent for more than a few days.

The chief has also attempted to promote the interests of his own family members and Ndu workers in preference to others, thus creating tensions and conflicts within the labour force. Initially, he demanded that all leading positions on the estate, which were not reserved for expatriate staff, should be occupied by members of his own family, irrespective of their professional qualifications. This claim was successfully

4 Speech of the Fon of Ndu on the occasion of the workers' welcome ceremony to the CDC management at the Ndu Tea Estate on 9 April 1977, in File MTLS/DILSI/NK/17, Ndu Tea Estate - General Correspondence.

5 Ibid. 


\section{CHIEFTAINCY AND LABOUR CONTROL \\ Piet Konings}

contested by the union's General Secretary. The chief then dropped this claim, only to advocate that management give preference to Ndu workers should vacancies for such positions occur. This caused a good deal of unrest among the workers in the early '70s, when a struggle for promotion was going on between two supervisors, one of them hailing from Ndu. Although the Ndu man was less qualified for a senior post, he was eventually appointed to please the chief of Ndu.

This does not mean that the chief of Ndu has always neglected to defend the interests of the estate workers as a whole. Following the takeover of the estate by the CDC in 1977, for example, he condemned the frequent transfers of Ndu Estate workers to the corporation's coastal estates.

\section{Conclusion}

Contrary to the existing studies of ethnic authorities in the Zambian and Ghanaian mines, this study has demonstrated that chieftaincy in the Bamenda Grassfields has continued to play an important intermediary role between capital and labour. This seems to be particularly because capitalism has not yet penetrated deeply in this area and chieftaincy still occupies a powerful, even sacred, position in society. In these circumstances, estate management has tended to rely on the local chief for both the supply of land and labour and control over workers at the workplace.

This explanation is supported by my previous research on the role of chieftaincy in capitalist development in Ghana and Cameroon. In Northern Ghana, where similar circumstances prevail to those in the Bamenda Grassfields, I found that local chiefs have also played a key intermediary role in the supply and control of labour on newly created public irrigation projects and capitalist rice farms (Konings 1986). In coastal areas of Anglophone Cameroon, by contrast, where the plantation economy introduced during German colonial rule (1884-1916) has extensively undermined local institutions and value systems and where chieftaincy is generally weak (Ardener 1962; Geschiere 1993), I have found that local chiefs have played a less significant intermediary role in the supply and control of labour than they have in the Bamenda Grassfields. It is therefore not surprising that the local chiefs there did not protest in 1954 when the CDC management began employing predominantly female pluckers on the newly created Tole Tea Estate (de la Vega 1971; Konings 1995).

Unlike Epstein and Crisp, who tend to view the intermediary role of chieftaincy in the Zambian and Ghanaian mines almost exclusively as an expression of labour control strategies on the part of management and the state, chieftaincy in Ndu has never been solely instrumental in labour control and functional to the demands of capital. While the chief was generally a reliable partner in development and often sided with the management, he also distinguished himself as the custodian of 


\section{JOURNAL OF LEGAL PLURALISM \\ 1996 - nr. 37-38}

'tradition' and the champion of the interests of his (Ndu) subjects. As a consequence, he firmly resisted management preference for female labour and was inclined to endorse his subjects' persistent loyalty to certain 'traditional' norms and values which conflicted with the capitalist work ethic. He was also inclined to put pressure on management to advance the careers of Ndu men on the estate, a practice which led to frequent conflicts between Ndu and other workers. This tendency of chiefs to defend 'traditional' values and local interests in development projects in their local communities, was also manifested in Northern Ghana (Konings 1986).

Nevertheless, there is sufficient evidence to support the view of Lentz and Erlmann that the intermediary role of chieftaincy has weakened in the course of time. First, the developing trade unionism on the estate attempts to transcend ethnic allegiances and defend the class interests of all workers against state and management. The chief's keen opposition to the union, undoubtedly arising from his concern for the preservation of 'traditional' authority and values, eventually proved futile as he was accused of being a management stooge and the union leaders were hailed as the 'true' representatives of workers' interests. Second, there has been the emergence of new power-holders who can serve as ethnic brokers on the estate, as well as of several ethnic associations which promote ethnic solidarity and assistance. As a result, the chief's intermediary role has become marginalized. At present his assistance in labour control on the estate is needed by management, state and union alike primarily in critical situations, as when workers engage in collective modes of resistance against control and exploitation. Upon any failure of the union and the Labour Department - the 'modern' brokers between capital and labour - to settle labour disputes, a final appeal is made to the 'traditional' broker to use his still existing religious and moral authority over the workers to help reassert managerial control over the labour process.

Finally, my study would appear to confirm the remarkable resilience of chieftaincy and its capacity to adapt to changing conditions (van Rouveroy van Nieuwaal 1987). The present chief of Ndu is an excellent example of the present tendency in the Bamenda Grassfields and elsewhere in Africa to enthrone well-educated youths capable of 'modernizing' traditional value systems. Soon after his installation, the present chief allowed women to work on the estate on a permanent basis, which might be seen as a significant contribution of chieftaincy to women's emancipation in the Bamenda Grassfields. He has also established a cordial relationship with union leadership, inviting it for regular consultations. In fact, he has been able to integrate this potentially rival source of power into both the 'modern' and 'traditional' structures of authority in the local community: some union leaders are members of the elite 'Development Committee' and others have been co-opted as non-hereditary title-holders in the local community's 'traditional' hierarchy of authority. 


\title{
CHIEFTAINCY AND LABOUR CONTROL \\ Piet Konings
}

\section{References}

\author{
ARDENER, Edwin \\ 1962 Divorce and Fertility: An African Study. London: Oxford University \\ Press.
}

BATES, Robert $\mathrm{H}$.

1981 Markets and States in Tropical Africa: The Political Basis of Agricultural Policies. Berkeley/Los Angeles: University of California Press.

BINSBERGEN, Wim van

1993 "Kazanga -Ethnicité en Afrique entre État et tradition." Afrika Focus 9/12: $16-41$.

CHAUNCEY, George Jr.

1981 "The Locus of Reproduction: Women's Labour in the Zambian Copperbelt 1927-1953." Journal of Southern African Studies 7 /2: 135164.

CHILVER, Sally M. and Phyllis M. KABERRY

1967 Traditional Bamenda: The Precolonial History and Ethnography of the Bamenda Grassfields. Buea: Ministry of Primary Education and Social CRISP, Jeff Welfare/West Cameroon Antiquities Commission.

1984 The Story of an African Working Class: Ghanaian Miners' Struggles, 1870-1980. London: Zed Books Ltd.

ELSON, Diane and Ruth PEARSON

1984 "'Nimble Fingers Make Cheap Workers': An Analysis of Women's Employment in Third World Export Manufacturing. " Pp. 121-141 in P. Waterman (ed.), For a New Labour Internationalism. The Hague: Ileri.

EPSTEIN, Arnold L.

1958 Politics in an Urban African Community. Manchester: Manchester FISIY, Cyprian F. University Press.

1992 Power and Privilege in the Administration of Law: Land Law Reforms and Social Differentiation in Cameroon. Leiden: African Studies Centre, Research Report no. 48.

FREUND, Bill

1981 Capital and Labour in the Nigerian Tin Mines. Harlow, Essex: Longman. GESCHIERE, Peter L.

1989 "Moderne Mythen: Cultuur en Ontwikkeling in Afrika." Inaugural Lecture, University of Leiden.

1993 "Chiefs and Colonial Rule in Cameroon: Inventing Chieftaincy, French and British Style." Africa 63 /2: 151-175.

GOHEEN, Mitzi

1993 "Les champs appartiennent aux hommes, les récoltes aux femmes: 


\section{JOURNAL OF LEGAL PLURALISM \\ 1996 - nr. 37-38}

Accumulation dans la région de Nso." Pp 225-255 in Geschiere, P., and P. Konings (eds.), Itinéraires d'accumulation au Cameroun. Paris: Karthala.

JEFFRIES, M.D.W.

1962 "The Wiya Tribe." African Studies 21/2: 83-104.

KABERRY, Phyllis M.

1952 Women of the Grassfields: A Study of the Economic Position of Women in Bamenda, British Cameroons. London: HMSO.

KONINGS, Piet

1986 The State and Rural Class Formation in Ghana: A Comparative Analysis. London and Boston: Kegan Paul International.

1993 Labour Resistance in Cameroon. London: James Currey.

1995 Gender and Class in the Tea Estates of Cameroon. Hampshire: Avebury, African Studies Research Series no. 5.

KURIAN, Rachel

1982 Women Workers in the Sri Lanka Plantation Sector. Geneva: International Labour Office.

LENTZ, Carola and Veit ERLMANN

1989 "A Working Class in Formation?: Economic Crisis and Strategies of Survival among Dagara Mine Workers in Ghana." Cahiers d'Études Africaines 29/1: 69-111.

MEEBELO, Henry S.

1986 African Proletarians and Colonial Capitalism. Lusaka: Kenneth Kaunda Foundation.

MEILLASSOUX, Claude

1975 Femmes, greniers et capitalisme. Paris: Maspero.

MILLEN, B.H.

1963 The Political Role of Labour in Developing Countries. Washington: The Brookings Institution.

NKWI, Paul N. and Jean-Pierre WARNIER

1982 Elements for a History of the Western Grassfields. Yaoundé: SOPECAM. OBBO, Christine

1980 African Women: Their Struggles for Economic Independence. London: Zedd Press.

PARPART, Jane L.

1986 "Class and Gender in the Copperbelt: Women in Northern Rhodesian Copper Mining Communities, 1926-1946." Pp. 141-160 in Robertson, C., and I. Berger (eds.), Women and Class in Africa. New York/London: Africana Publishing Company.

PROBST, Peter and Brigitte BÜHLER

1990 "Patterns of Control in Medicine, Politics, and Social Change amongst the Wimbum, Cameroon Grassfields." Anthropos 85 /4-6: 447-454. 


\section{CHIEFTAINCY AND LABOUR CONTROL \\ Piet Konings}

\section{ROBOTHAM, Don}

1989 Militants or Proletarians?: The Economic Culture of Underground Gold Miners in Southern Ghana, 1906-1976. Cambridge: Cambridge African Monographs no. 12.

ROUVEROY VAN NIEUWAAL, E. Adriaan B. van

1987 "Chiefs and African States: Some Introductory Notes and an Extensive Bibliography on African Chieftaincy." Journal of Legal Pluralism 25-26: $1-46$.

RUEL, Malcolm J.

1960 "The Banyang of Mamfe Division." Pp. 230-247 in Ardener E, Ardener $\mathrm{S}$, and W.A. Warmington, Plantation and Village in the Cameroons. London: Oxford University Press.

STICHTER, Sharon B. and Jane L. PARPART (eds.)

1988 Patriarchy and Class: African Women in the Home and the Workforce. Boulder, Colorado: Westview Press.

VEGA, Bernard de la

1971 "La Plantation de Thé de Tole (Cameroun Occidentale), Travail d'Études et de Recherches." University of Bordeaux: Institute of Geography.

WALKER, Cherryl (ed.)

1982 Women and Gender in Southern Africa to 1945. Cape Town: David Philips/London: James Currey.

WOLPE, Harold (ed.)

1980 The Articulation of Modes of Production: Essays from 'Economy and Society'. London: Routledge \& Kegan Paul. 